\title{
EFEKTIVITAS IMPLEMENTASI REGROUPING SEKOLAH DASAR DI SD NO. 2 BANJAR TEGAL KECAMATAN BULELENG
}

\author{
Luh Indrayani \\ Pendidikan Ekonomi, Fakultas Ekonomi dan Bisnis \\ Universitas Pendidikan Ganesha \\ Singaraja, Indonesia
}

Email : luh.indrayani@yahoo.co.id

\begin{abstract}
Abstrak
Penelitian ini bertujuan untuk mendeskripsikan: (1) manajemen sekolah, (2) iklim sekolah, (3) kualitas pembelajaran, dan (4) kendala-kendala yang dialami kepala sekolah dan guru dalam melaksanakan kegiatan sekolah setelah regrouping di SD No. 2 Banjar Tegal Kecamatan Buleleng. Hasil penelitian yang ditemukan adalah: (1) manajemen sekolah secara umum berjalan efektif. Efektivitas juga terjadi pada manajemen pembelajaran, manajemen kesiswaan, manajemen kepegawaian, manajemen sarana/prasarana, manajemen keuangan, manajemen humas, dan manajemen layanan khusus, (2) setelah terjadi regrouping sekolah menunjukkan iklim sekolah yang baik, meliputi lingkungan yang kondusif dan fasilitas belajar yang menyenangkan, (3) kualitas pembelajaran menunjukkan kategori baik, hal ini dapat dilihat dari apersepsi, eksplorasi, konsolidasi pembelajaran, pembentukan kompetensi, sikap dan perilaku, penilaian formatif, dan kemampuan guru melaksanakan proses pembelajaran yang terdiri dari rencana pembelajaran dan proses pembelajaran, dan (4) setelah terjadi regrouping kepala sekolah dan guruguru tidak mengalami kendala yang berarti.
\end{abstract}

Kata-kata Kunci: Efektivitas, Implementasi, Regrouping, Sekolah Dasar.

\section{Abstract}

This study aimed at describing: (1) school management, (2) school climate, (3) quality of learning, and (4) constraints that the principal and teachers faced in conducting school activities after regrouping at SD No. 2 Banjar Tegal Buleleng regency. This study used an evaluation design and qualitative-descriptive approach. The results that were obtained are: (1) in general, the school management effectively. The effectiveness was also found in the teaching and learning management, student management, administrative staff management, facilities management, financial management, public relations management, and special service management, (2) after regrouping the school showed a good atmosphere. This was indicated in a conducive environment and comfortable facilities, (3) the teaching and learning quality was good. This could be seen from apperception, exploration, consolidation of teaching and learning, competencies, attitude and behavior development, formative evaluation, and teacher's ability in implementing the teaching and learning process that consisted of teaching plan and teaching and 
learning process, and (4) after regrouping the school principal and teachers did not face significant constraints.

Keywords: Effectiveness, Implementation, Regrouping, Primary School.

\section{PENDAHULUAN}

Pendidikan memegang peranan yang sangat penting dalam proses peningkatan sumber daya manusia, karena pendidikan bagi kehidupan umat manusia merupakan kebutuhan mutlak yang harus dipenuhi sepanjang hayat. Sekolah dasar merupakan satuan pendidikan yang berfungsi menyiapkan lulusannya mencapai beberapa sasaran. Setiap sekolah dasar tentu menginginkan mencapai mutu pendidikan yang telah ditetapkan, namun banyak masalah mutu yang dihadapi di dunia pendidikan. Untuk mencapai mutu pendidikan yang tinggi sekolah dasar harus didukung oleh administrator, guru, konselor, tata usaha yang bermutu atau profesional, memiliki sarana dan prasarana pendidikan, fasilitas, media dan sumber belajar yang memadai baik mutu maupun jumlah, biaya yang mencukupi, manajemen yang tepat serta lingkungan belajar yang mendukung. Tetapi pada kenyataannya masih ada sekolah dasar yang mendapatkan jumlah siswa yang tidak memenuhi standar, gedung dan ruang belajar yang sudah rusak serta jumlah guru yang tidak merata. Keadaan ini berdampak pada efektivitas dan efisiensi pengelolaan sekolah dasar, oleh karena itu dalam rangka efisiensi pembiayaan dalam operasionalisasinya perlu dilaksanakan regrouping. Regrouping SD adalah usaha penyatuan dua unit SD atau lebih menjadi satu kelembagaan SD dan diselenggarakan dalam satu pengelolaan. Regrouping ini merupakan upaya untuk mengatasi kekurangan tenaga guru, peningkatan mutu serta efisiensi biaya bagi perawatan gedung sekolah.

Dari uraian di atas, ada 4 masalah yang diangkat dalam tulisan ini: (1) bagaimanakah manajemen sekolah di SD No. 2 Banjar Tegal Kecamatan Buleleng?, (2) bagaimanakah iklim sekolah di SD No. 2 Banjar Tegal Kecamatan Buleleng?, (3) bagaimanakah kualitas pembelajaran di SD No. 2 Banjar Tegal Kecamatan Buleleng?, dan (4) kendala-kendala apa yang dialami kepala sekolah dan guru dalam melaksanakan kegiatan sekolah setelah di-regrouping?

Tujuan penelitian ini adalah: (1) untuk mendeskripsikan manajemen sekolah di SD No. 2 Banjar Tegal Kecamatan Buleleng, (2) untuk mendeskripsikan iklim sekolah di SD No. 2 Banjar, Tegal Kecamatan Buleleng, (3) untuk mendeskripsikan kualitas pembelajaran di SD No. 2 Banjar Tegal Kecamatan Buleleng, dan (4) untuk mendeskripsikan kendala-kendala yang dialami kepala sekolah dan guru dalam melaksanakan kegiatan sekolah setelah di-regrouping.

Adapun manfaat dari penelitian ini sebagai berikut: (1) bagi Dinas Pendidikan, sebagai bahan pertimbangan untuk melaksanakan regrouping dan pemberian pembinaan terhadap sekolah hasil regrouping, (2) bagi kepala sekolah, sebagai bahan pertimbangan dalam upaya meningkatkan mutu pendidikan di sekolah dasar, (3) bagi guru, sebagai bahan masukan untuk meningkatkan 
profesionalisme dalam kegiatan belajar mengajar. Sedaangkan hasil penelitian ini dapat dipakai sebagai bahan pertimbangan bagi peneliti yang lain yang ingin meneliti masalah yang lebih luas secara mendalam.

Dalam kaitannya dengan penelitian ini, ada beberapa teori yang digunakan oleh peneliti yaitu sekolah dasar yang bermutu baik ialah sekolah dasar yang mampu berfungsi sebagai wadah proses edukasi, wadah proses sosialisasi dan wadah proses transformasi, sehingga mampu mengantarkan anak didik menjadi seorang terdidik, memiliki kedewasaan mental dan sosial, serta memiliki ilmu pengetahuan dan teknologi, termasuk juga kebudayaan bangsa. Regrouping SD adalah usaha penyatuan dua unit SD atau lebih menjadi satu kelembagaan SD dan diselenggarakan dalam satu pengelolaan. Sergiovanni, Burlingame, Coombs dan Thurston mendefinisikan manajemen sebagai "process of working with and through others to accomplish organizational goals effecienctly", yaitu proses kerjasama dengan dan melalui (mendayagunakan) orang lain untuk mencapai tujuan organisasi secara efisien (Bafadal, 2003:39). Langkah-langkah manajemen meliputi, perencanaan (planning), pengorganisasian (organizing), pengerahan (leading) dan pengawasan (controlling). Manajemen sekolah dasar terdiri dari manajemen pembelajaran, manajemen kesiswaan, manajemen kepegawaian, manajemen sarana/prasarana, manajemen keuangan, manajemen humas, dan manajemen layanan khusus. Iklim sekolah ini meliputi lingkungan yang kondusif dan fasilitas belajar yang menyenangkan. Kualitas pembelajaran meliputi apersepsi, eksplorasi, konsolidasi pembelajaran, pembentukan kompetensi, sikap dan perilaku, penilaian formatif dan kemampuan guru dalam melaksanakan pembelajaran yang meliputi rencana pembelajaran dan proses pembelajaran.

\section{METODE}

Penelitian ini menggunakan rancangan evaluatif dan pendekatan deskriptif kualitatif karena dilakukan untuk mendiskripsikan manajemen sekolah, iklim sekolah, kualitas pembelajaran, dan kendala-kendala yang dialami kepala sekolah dan guru dalam melaksanakan kegiatan sekolah setelah di-regrouping. Dalam penelitian ini yang menjadi populasi adalah kepala sekolah dan guru di SD No. 2 Banjar Tegal Kecamatan Buleleng. Mengingat jumlah kepala sekolah dan guru tidak terlalu banyak, maka dalam penelitian ini pengambilan datanya tidak menggunakan sistem sampling. Metode pengumpulan data terdiri dari dokumentasi, angket, wawancara dan observasi. Kebenaran data tergantung dari79instrument pengumpul data yang harus memenuhi dua persyaratan yaitu validitas dan reliabilitas. Metode analisis data terdiri analisis efektifitas manajemen sekolah (guru), iklim sekolah, kualitas pembelajaran dan efektifitas manajemen sekolah (kepala sekolah) dari: 
Tabel 1. Kategori skor efektifitas manajemen sekolah (guru)

\begin{tabular}{ll}
\hline \multicolumn{1}{c}{ Kriteria } & \multicolumn{1}{c}{ Kategorisasi } \\
\hline$M+1,5 S D$ Sangat Efektif \\
$M-0,5 S D / d M+1,5 S D$ & Efektif \\
$M-1,5 S D$ S $/ d=-0,5 S D$ & Kurang Efektif \\
$M-1,5 S D$ & Tidak Efektif \\
\hline
\end{tabular}

(Dimodifikasi dari Masidjo, 1995:132)

Tabel 2. Kategori skor iklim sekolah

\begin{tabular}{ll}
\hline \multicolumn{1}{c}{ Kriteria } & \multicolumn{1}{c}{ Kategorisasi } \\
\hline$M+1,5 S D$ S & Sangat Baik \\
$M-0,5 S D ~ M+1,5 S D$ & Baik \\
$M-1,5 S D$ S $/ d M-0,5 S D$ & Kurang Baik \\
$M-1,5 S D$ & Tidak Baik \\
\hline
\end{tabular}

(Dimodifikasi dari Masidjo, 1995:132)

Tabel 3. Kategori skor kualitas pembelajaran

\begin{tabular}{|c|c|}
\hline Kriteria & Kategorisasi \\
\hline $\begin{array}{l}M+1,5 S D \\
M-0,5 S D \text { s/d } M+1,5 S D \\
M-1,5 S D \text { s } / d M-0,5 S D \\
M-1,5 S D\end{array}$ & $\begin{array}{l}\text { Sangat Baik } \\
\text { Baik } \\
\text { Kurang Baik } \\
\text { Tidak Baik }\end{array}$ \\
\hline
\end{tabular}

(Dimodifikasi dari Masidjo, 1995:132)

Tabel 4. Kategori skor efektifitas manajemen sekolah (kepala sekolah)

\begin{tabular}{ll}
\hline \multicolumn{1}{c}{ Rentangan Skor } & \multicolumn{1}{c}{ Kategorisasi } \\
\hline $80 \%-100 \%$ & Sangat Efektif \\
$60 \%-79 \%$ & Efektif \\
$50 \%-59 \%$ & Kurang Efektif \\
$<50 \%$ & Tidak Efektif \\
\hline
\end{tabular}

(Dimodifikasi dari Masidjo, 1995:132)

\section{HASIL DAN PEMBAHASAN}

SD No. 2 Banjar Tegal Kecamatan Buleleng didirikan tanggal 1 Januari 1967, terletak di Jalan Parikesit Singaraja. Tanggal 29 Januari 2004 terjadi penggabungan dengan SD No. 4 Banjar Tegal Kecamatan Buleleng yang berada dalam satu halaman. Penggabungan ini berdasarkan surat keputusan Bupati Buleleng Nomor 519 tahun 2004 tanggal 27 Juli 2000, dengan Nomor Statistik Sekolah (NSS) 101220101038. Temuan penelitian dapat dilihat pada beberapa tabel deskirpsi sebagai berikut. 
Tabel 5. Manajemen sekolah menurut guru

\begin{tabular}{clccc}
\hline No. & Aspek Manajemen & Rata-rata Skor & Kriteria & Kategorisasi \\
\hline 1 & Manajemen & 73,8 & $\geq 72,1-<78,8$ & Efektif \\
& Keseluruhan & & & \\
2 & Pembelajaran & 29,3 & $\geq 29-<30,1$ & Efektif \\
3 & Kesiswaan & 18,5 & $\geq 18,2-<19,3$ & Efektif \\
4 & Sarana/Prasarana & 26 & $\geq 24,9-<29,3$ & Efektif \\
\hline
\end{tabular}

Tabel 6. Hasil manajemen sekolah menurut kepala sekolah

\begin{tabular}{clccc}
\hline No. & Aspek Manajemen & Skor & Rentangan Skor & Kategorisasi \\
\hline 1 & Manajemen Keseluruhan & 169 & $153,6-192$ & Sangat Efektif \\
2 & Pembelajaran & 42 & $35,2-44$ & Sangat Efektif \\
3 & Kesiswaan & 17 & $16-20$ & Sangat Efektif \\
4 & Kepegawaian & 28 & $25,6-32$ & Sangat Efektif \\
5 & Sarana/Prasarana & 10 & $9,6-12$ & Sangat Efektif \\
6 & Keuangan & 23 & $19,2-24$ & Sangat Efektif \\
7 & Humas & 32 & $32-40$ & Sangat Efektif \\
8 & Layanan Khusus & 17 & $16-20$ & Sangat Efektif \\
\hline
\end{tabular}

Tabel 7. Kualitas Pembelajaran

\begin{tabular}{llccc}
\hline No & Aspek Kualitas Pembelajaran & $\begin{array}{c}\text { Rata-rata } \\
\text { Skor }\end{array}$ & Kriteria & $\begin{array}{c}\text { Kategoris } \\
\text { asi }\end{array}$ \\
\hline 1 & $\begin{array}{l}\text { Kualitas Pembelajaran } \\
\text { Keseluruhan }\end{array}$ & 59,7 & $\geq 58,2-<64,1$ & Baik \\
2 & $\begin{array}{l}\text { Kemampuan Guru Dalam } \\
\text { Melaksanakan Pembelajaran }\end{array}$ & 232,5 & $\geq 230,7-<237,8$ & Baik \\
3 & Apersepsi & 11,3 & $\geq 10,9-<12,5$ & Baik \\
4 & Eksplorasi & 10,7 & $\geq 10,4-<11,5$ & Baik \\
5 & Konsolidasi Pembelajaran & 14,5 & $\geq 14,2-<15,3$ & Baik \\
6 & $\begin{array}{l}\text { Pembentukan Kompetensi, } \\
\text { Sikap dan Perilaku }\end{array}$ & 11,7 & $\geq 11,4-<12,5$ & Baik \\
7 & $\begin{array}{l}\text { Penilaian Formatif } \\
8\end{array}$ & 11,5 & $\geq 11,2-<12,3$ & Baik \\
& $\begin{array}{l}\text { Komponen Rencana } \\
9\end{array}$ & 96,5 & $\geq 95,7-<98,9$ & Baik \\
& $\begin{array}{l}\text { Komponajan Pran } \\
\text { Pembelajaran }\end{array}$ & 136 & $\geq 135-<138,9$ & Baik \\
\hline
\end{tabular}

Tabel 8. Iklim sekolah

\begin{tabular}{|c|c|c|c|c|}
\hline No. & Aspek Iklim sekolah & $\begin{array}{l}\text { Rata-rata } \\
\text { Skor }\end{array}$ & Kriteria & Kategorisasi \\
\hline 1 & $\begin{array}{l}\text { Iklim Sekolah } \\
\text { Keseluruhan }\end{array}$ & 41,2 & $\geq 39,8-<45,6$ & Baik \\
\hline $\begin{array}{l}2 \\
3\end{array}$ & $\begin{array}{l}\text { Lingkungan } \\
\text { Fasilitas }\end{array}$ & $\begin{array}{c}27 \\
14,2\end{array}$ & $\begin{array}{l}\geq 26,4-<28,7 \\
\geq 13,4-<16,6\end{array}$ & $\begin{array}{l}\text { Baik } \\
\text { Baik }\end{array}$ \\
\hline
\end{tabular}


Manajemen sekolah di SD No. 2 Banjar Tegal Kecamatan Buleleng mencakup kegiatan manajemen pembelajaran, manajemen kesiswaan, manajemen kepegawaian, manajemen sarana/prasarana, manajemen keuangan, manajemen humas, dan manajemen layanan khusus. Hasil penelitian terhadap manajemen sekolah di SD No. 2 Banjar Tegal Kecamatan Buleleng setelah regrouping berjalan efektif. Oleh karena itu, baik kepala sekolah maupun guru dapat meningkatkan pendayagunaan semua komponen sekolah dasar, baik komponen manusia maupun komponen bukan manusia yang dimiliki sekolah melalui kegiatan manajemen sekolah dasar. Kepala sekolah mempunyai wewenang dan tanggung jawab penuh atas penyelenggaraan pendidikan dalam lingkungan sekolahnya.

Hasil penelitian terhadap iklim sekolah di SD No. 2 Banjar Tegal Kecamatan Buleleng setelah regrouping berjalan baik. Ini berarti bahwa dalam hubungannya dengan regrouping, sekolah telah mampu menciptakan iklim sekolah yang kondusif serta ditunjang oleh berbagai fasilitas belajar yang menyenangkan. Hasil penelitian terhadap kualitas pembelajaran di SD No. 2 Banjar Tegal Kecamatan Buleleng setelah regrouping berjalan baik. Ini berarti bahwa guru mampu melaksanakan proses pembelajaran dengan baik. Mereka telah mampu melaksanakan apersepsi, eksplorasi, konsolidasi pembelajaran, pembentukan kompetensi, sikap dan perilaku, penilaian formatif dan kemampuan guru dalam melaksanakan pembelajaran yang meliputi rencana pembelajaran dan proses pembelajaran.

\section{SIMPULAN DAN SARAN}

Berdasarkan uraian hasil penelitian dapat disimpulkan sebagai berikut: (1) secara umum manajemen sekolah di SD No. 2 Banjar Tegal Kecamatan Buleleng setelah regrouping berjalan efektif. Efektivitas manajemen sekolah juga terjadi pada setiap komponen yaitu manajemen pembelajaran, manajemen kesiswaan, manajemen kepegawaian, manajemen manajemen keuangan, manajemen humas, dan manajemen layanan khusus, (2) setelah regrouping SD No. 2 Banjar Tegal Kecamatan Buleleng menunjukkan iklim sekolah yang baik (kondusif). Iklim sekolah ini meliputi lingkungan yang kondusif dan fasilitas belajar yang menyenangkan, (3) para guru di SD No. 2 Banjar Tegal Kecamatan Buleleng telah mampu melaksanakan proses pembelajaran dalam kategori baik. Mereka telah mampu melaksanakan apersepsi, eksplorasi, konsolidasi pembelajaran, pembentukan kompetensi, sikap dan perilaku, penilaian formatif dan kemampuan guru dalam melaksanakan pembelajaran yang meliputi rencana pembelajaran dan proses pembelajaran, dan (4) setelah terjadi regrouping kepala sekolah dan guru-guru tidak mengalami kendala yang berarti.

Kebijakan regrouping bagi sekolahsekolah yang mempunyai kasus sama dapat terus dilanjutkan. Dinas Pendidikan perlu melaksanakan regrouping bagi sekolah dasar yang telah memenuhi syarat regrouping agar tujuan regrouping untuk meningkatkan efektivitas dan efisiensi penyelenggaraan kegiatan belajar mengajar pendidikan dasar dapat tercapai. Maka dapat disarankan bahwa sekolah dan guru harus mampu mempertahankan dan meningkatkan 
sistem manajemen sekolah yang sudah efektif sehingga nantinya dapat mencapai tujuan yang ditetapkan dengan lebih baik dan dinas Pendidikan sedapat mungkin melakukan pemantauan secara berkala sehingga kondisi yang tercipta akibat regrouping dapat dipertahankan bahkan dijadikan contoh dalam pelaksanaan sekolah-sekolah yang lain.

\section{DAFTAR PUSTAKA}

Aqib, Zainal. 2002. Profesionalisme Guru dalam Pembelajaran. Cetakan Pertama. Surabaya: Insan Cendekia.

Arcaro, Janice. 1995. Creating Quality in the Classroom. First published. USA: St. Lucie Press.

Arikunto, Suharsimi. 2000. Manajemen Penelitian. Cetakan Kelima. Jakarta: Rineka Cipta.

Azwar, Saifuddin. 2004. Metode Penelitian. Cetakan Kelima. Yogyakarta: Pustaka Pelajar.

Bafadal, Ibrahim. 2003a. Manajemen Perlengkapan Sekolah Teori dan Aplikasinya. Cetakan Pertama. Jakarta: Bumi Aksara. 2003b. Manajemen Peningkatan Mutu Sekolah Dasar dari Sentralisai Menuju Desentralisasi. Cetakan Pertama. Jakarta: Bumi Aksara. , 2004. Peningkatan Profesionalisme Guru Sekolah Dasar dalam Rangka Manajemen Peningkatan Mutu Berbasis Sekolah. Cetakan Kedua. Jakarta: Bumi Aksara.

Candiasa, I Made. 2004. Analisis Butir. Singaraja:Unit Penerbitan IKIP Negeri Singaraja.

Departemen Pendidikan Nasional Direktorat Jenderal Pendidikan Dasar dan Menengah Direktorat Sekolah Lanjutan Tingkat Pertama.
2001. Manajemen Peningkatan Mutu Berbasis Sekolah Buku 1 Konsep dan Pelaksanaan. Edisi Ketiga. Jakarta: Proyek Peningkatan Mutu SLTP.

Direktur Jenderal Pembangunan Daerah Departemen Dalam Negeri. 1998.

Pedoman

Pelaksanaan

Penggabungan

Sekolah Dasar. Jakarta:

Departemen Dalam Negeri Republik Indonesia.

Djamarah, Syaiful Bahri. 2000. Guru dan Anak Didik dalam Interaksi Edukatif. Cetakan Pertama. Jakarta: Rineka Cipta.

Hadi, Sutrisno. 2000. Statistik. Jilid 2. Cetakan Ketujuhbelas. Yogyakarta: Andi.

Hamalik, Oemar. 2002. Perencanaan Pengajaran Berdasarkan Pendekatan Sistem. Cetakan Pertama. Jakarta: Bumi Aksara.

Hutabarat, E.P. 1995. Cara Belajar Pedoman Praktis untuk Belajar Secara Efisien dan Efektif Pegangan Bagi Siapa Saja yang Belajar di Perguruan Tinggi. Cetakan Ketiga. Jakarta: Gunung Mulia.

Ihsan, Fuad. 2003. Dasar-dasar Kependidikan. Cetakan Ketiga. Jakarta: Rineka Cipta.

Instruksi Presiden Republik Indonesia Nomor 1 Tahun 1994 tentang Pelaksanaan Wajib Belajar Pendidikan Dasar.

Keputusan Menteri Pendidikan dan Kebudayaan Republik Indonesia Nomor 0274/O/1996 tentang Petunjuk Pelaksanaan Urusan Pendidikan dan Kebudayaan yang Diserahkan Kepada Daerah Tingkat Il Percontohan. 
Keputusan Menteri Permukiman dan Prasarana Wilayah Nomor: 332/KPTS/M/2002 tentang Pedoman Teknis Pembangunan Bangunan Gedung Negara.

Koontz, Harold dan O'Donnell, Cyril. 1955. Principles of Manajement an Analysis of Manajerial Function. New York: McGraw-Hill Book Company.

Manullang M. 2004. Dasar-Dasar Manajemen. Cetakan Ketujuh Belas. Yogyakarta: Gadjah Mada University Press.

Masidjo, Ign. 1995. Penelitian Pencapaian Hasil Belajar Siswa di Sekolah. Yogyakarta: Kanisius.

Moedjiarto. 2001. Karakteristik Sekolah Unggul. Duta Graha Pustaka.

Mulyasa. 2004a. Implementasi Kurikulum 2004 Panduan Pembelajaran KBK. Cetakan Pertama. Bandung: Remaja Rosdakarya.

------, 2004b. Manajemen Berbasis Sekolah Konsep, Strategi, dan Implementasi. Cetakan Ketujuh. Bandung: Remaja Rosdakarya.

Nana, Syaodih Sukmadinata, dkk. 2003. Pengendalian Mutu Pendidikan Sekolah Dasar. Bandung: Kesuma Karya.

Nana, Syaodih Sukmadinata. 2004. Landasan Psikologi Proses Pendidikan. Cetakan Kedua. Bandung: Remaja Rosdakarya.

Nasution, S. 2004. Didaktik Asas-Asas Mengajar. Cetakan Ketiga. Jakarta: Bumi Aksara.

Peraturan Pemerintah Republik Indonesia Nomor 6 Tahun 1988 tentang Koordinasi Kegiatan Instansi Vertikal di Daerah.

Peraturan Pemerintah Republik Indonesia Nomor 8 Tahun 1995 tentang
Penyerahan Sebagian Urusan Pemerintah Kepada Dua Puluh Enam Daerah Tingkat II Percontohan.

Peraturan Pemerintah Nomor 19 Tahun 2005. Standar Nasional Pendidikan. Bandung: Fokusmedia.

Peraturan Pemerintah Republik Indonesia Nomor 45 Tahun 1992 tentang Penyelenggaraan Otonomi Daerah Titik Berat Pada Daerah Tingkat II.

Riduwan, 2004. Metode \& Teknik Menyusun Tesis. Cetakan Pertama. Bandung: Alfabeta.

Rohani, Ahmad. 2004. Pengelolaan Pengajaran. Cetakan Kedua. Jakarta: Rineka Cipta.

Sagala, Syaiful. 2004. Manajemen Berbasis Sekolah \& Masyarakat Strategi Memenangkan Persaingan Mutu. Cetakan Pertama. Jakarta: PT Nimas Multima.

Sardiman, A.M. 2001. Interaksi \& Motivasi Belajar Mengajar. Cetakan Kedelapan. Jakarta: PT RajaGrafindo Persada.

Scheerens, Jaap. 2003. Menjadikan Sekolah Efektif. Terjemahaan AlJauhari, Abas. Improving School Effectiveness. 2000. Jakarta: Logos.

Shamadi, Kawit I Wayan. 2005. "Gaya Kepemimpinan Kepala Sekolah dan Motivasi Kerja Guru dalam Hubungannya dengan Kinerja Guru Sekolah Dasar Regrouping Kecil di Kabupaten Jembrana". Tesis: Tidak Dipublikasikan.

Subagyo, Pangestu. 1998. Statistik Deskriptif. Edisi Ketiga. Cetakan Ketiga. Yogyakarta: BPFE.

Sudjana, Nana. 2004. Dasar-Dasar Proses Belajar Mengajar. Cetakan Ketujuh. Bandung: Sinar Baru Algensindo. 
Sugiyono. 2004a. Metode Penelitian Bisnis. Cetakan Keenam. Bandung: Alfabeta.

------, 2004b. Stastistik untuk Penelitian. Cetakan Keenam. Bandung: Alfabeta.

Supriadi, Dedi. 2004. Membangun Bangsa Melalui Pendidikan. Cetakan Pertama. Bandung: Remaja Rosdakarya.

Suryosubroto, B. 1997. Proses Belajar Mengajar di Sekolah. Cetakan Pertama. Jakarta: Rineka Cipta.

Syafaruddin. 2002. Manajemen Mutu Terpadu dalam Pendidikan Konsep, Strategi, dan Aplikasi. Jakarta: Gramedia Widiasarana Indonesia.

Terry, George R, Rue, Leslie W. 2000. Dasar-Dasar Manajemen. Cetakan Ketujuh. Alih Bahasa: Ticoalu. Principles of Manajement. 1992. Jakarta: Bumi Aksara.

Tirtarahardja, Umar, dkk. 2005. Pengantar Pendidikan. Cetakan Pertama. Jakarta: Rineka Cipta.

Undang-Undang Dasar Negara Republik Indonesia Tahun 1945. Surabaya: Suritama Cipta Karya.

Undang-undang Republik Indonesia Nomor 20 Tahun 2003 tentang Sistem Pendidikan Nasional.

Usman, Uzer. 2003. Menjadi Guru Profesional. Cetakan Kelimabelas. Bandung: Remaja Rosdakarya. 